\title{
The Conjugated Triangle Method CTM of the detection of inconsistent bids in the construction industry
}

\author{
Hubert Anysz ${ }^{1, *}$, and Krzysztof Kaczorek ${ }^{1}$ \\ ${ }^{1}$ Warsaw University of Technology, Faculty of Civil Engineering, Institute of Building Engineering, \\ Division of Production Engineering and Construction Management, Al. Armii Ludowej 16, 00-637 \\ Warsaw, Poland
}

\begin{abstract}
The existing system of bids evaluation in the construction industry does not bring the clients the certainty if all placed bids comprise real, achievable prices. Especially in the road construction sector, where the earthworks create significant part of the works, comparing e.g. the price of $1 \mathrm{~km}$ of roads often gives misleading results. The paper comprises the complete proposal to modify the scope of information provided by offerors in the public procurements (in the construction industry) allowing the clients to determine easily if the contractors have placed the consistent offers i.e. if the bid prices are not too high and if the lowest bid price is not a dumping price. The Conjugated Triangle Method (CTM) of inconsistent bid detection in construction industry is based on the three inter-related parameters: means of production, time of works, on the value of works. Regardless of the offered price it should match the other two parameters.
\end{abstract}

\section{Introduction}

The system of public procurement provides public investors with the tool allowing for the choice of the optimum bid for building works execution. Both design documentation and technical specification describe the planned object in detail. The client sets essential assumptions, terms of a tender procedure giving (among others) required time for works execution, required building materials, the technology of selected works [1, 2]. All the aforementioned means make the bid price the most important criterion for the contractor choice. Even if it is not the only criterion, the bid price remains the decisive one for the client to choose the offer. Sometimes it happens that one of the bid prices is exceptionally low. The choice of that one is often a source of many problems appearing during the construction process [3]. In the case of the collusion - which is a forbidden practise - the participants discuss the bid values before placing offers. It leads to the situation when all bids take a relatively high value [4]. Both cases make the client's investment much less financially effective that it was planned.

\footnotetext{
${ }^{*}$ Corresponding author: h.anysz@il.pw.edu.p1
} 


\section{Existing system of the bids evaluation}

Currently public investors set the time of work execution and ask the offerors for price offers and proposed time schedules. For the planned building objects of higher value, some information about access to the critical building machinery and experienced personnel is required too. According to the limited information about production resources [3] and according to the fact the price offers and the time schedules are being prepared on different levels of detail [5], it is really difficult to evaluate if the offers are not too low or not too high. No problem occurs to recognize which bids are overpriced, not to be considered. None of them is usually chosen as the best one. As the bid price is the most influencing factor on the client's decision, they are naturally prone to choose the bid with the lowest value or near the lowest value. A key problem arises if the lowest bid is under-priced or not. When the under-priced offer is chosen as the best one, the contractor is not able to execute all works within the offered price. Thus the search for artificial problems during construction work execution emerges to force the client to increase the contract value [6]. On the other hand, if all bids fulfil the client's requirements and there are no formal mistakes in preparing offers, the client is forced to choose the cheapest one. The nonfinancial criteria rarely make a different choice, unless the client proves that the lowest bid represents unrealistic, under-the-market value of building works. The Polish legal system provides the contractors with legal tools to claim this kind decision of the client. This makes the tender procedure much longer than planned. The evidence of under-pricing a given bid can be made using the three following checks:

- comparing the value of bids in a given tender procedure,

- comparing the index prices of similar, completed already objects,

- comparing the unit prices for the specific types of planned construction works to the unit prices achieved on already completed projects.

All the checks mentioned above do totally assure if a given offer is under-priced. The evaluation based on the index prices of similar, already completed objects may not give the high-level certainty in assessing the bid as an under-priced. The massive and varying amount of earthworks, the different number of overpasses etc. has made the prices of $1 \mathrm{~km}$ of express roads in Poland varying from several to a few dozen of million PLN (2009-2013) [7]. Relying on the unit prices of building works is doubtful too, as it was proved the unit prices shown in tenders comprise indirect costs and the profit of the contractor $[8,9,10]$. While there is no obligation to assign them to each building work in the same proportion, it is hard to prove if the price is an under-market price for a given type of building work. Applying all of the above mentioned procedures to check if a given bid is on the market level or below, the answer is formulated with a given confidence. Finally, after long-lasting analysis and sessions, the decision is made in Poland by a dedicated chamber for public procurements KIO ( $p l$. Krajowa Izba Odwolawcza). The time-consuming process of excluding the under-priced bids and their high negative impact on the clients financial effectiveness has pushed the authors to invent the method of evaluating the bids in construction sector, allowing for quick working out the decision about exceptionally low bid in a given procedure.

\section{The Conjugated Triangle Method (CTM) of the bids evaluation}

The Conjugated Triangle Method (CTM) of the detection of inconsistent bids in the construction industry is based on the following three inter-related parameters $[9,11]$ :

- the means of production (M),

- the time of works (T),

- the value of works $(\mathrm{C})$. 
The liaisons (conjunctions) between pairs of these parameters exist every time [9, 12, 13] and arise from their nature (not from any subjective evaluation).

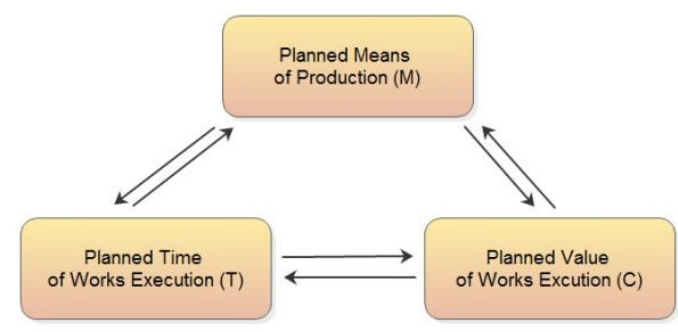

Fig. 1. The Conjugated Triangle and its elements [own elaboration].

If there is proper information provided in the offers, the clients - based on a number and types of means of production - can estimate the time of the work execution and compare it to the planned time $[14,15]$. The next check is to compare estimated cost of the production means, to the bid prices. This double check can provide precise information which of the low price bids are inconsistent and under-priced.

\subsection{The means of production and time of works execution (M-T)}

The conjunction (M-T) between the means of production assigned by the contractor to perform a given type of building work and the time necessary to execute them is evident. A pair of diggers can make the cut twice quicker than the one only [16]. This (M-T) conjunction is discrete and proportional, but only in case of a low number of machines. When too many diggers are working at the same time on the limited area, their total efficiency is lower than the efficiency of a single machine multiplied by the number of machines [17]. This finding shows a low practical meaning as the contractors are not equipped with an unlimited number of machines. It can be assumed that every machine added to the already working, increase their total efficiency proportionally.

\subsection{The means of production and the cost of works execution (M-C)}

This (M-C) conjunction shows a linear character too. Every means of production has its price (not considered a purchase price but an amount of money to pay for utilizing a given resource in a unit of time). The more resources we hire, the more we have to pay for them [18]. The differences in the prices of resources hired by different contractors exist, but there is no market reason that would make these differences high. The other problem that can be recognized are indirect costs. In fact, comparing the tenders for erecting the same building object it can be assumed that indirect costs influence the total cost of every contractor on near the same level.

\subsection{The time of works execution and the cost of it (T-C)}

The time-cost dependence is not linear in construction industry. There is optimum time $t_{\text {opt }}$ of work execution a given type (and number) of works for a chosen technology (see fig. 4) providing the minimum $\operatorname{cost} c_{\min }$ of work execution. 


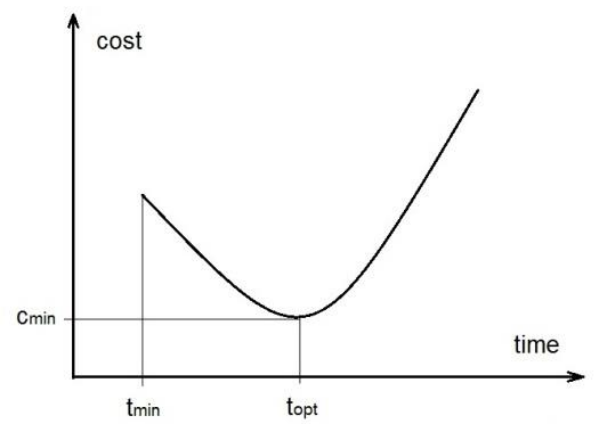

Fig. 2. The time-cost relationship for the construction works [19].

The technology is a lower limit of shortening the time of work execution. Applying the means of production very inefficiently we can extend the time of the work execution to infinity. The evaluation of the cost of works based on the time predicted for their execution is almost impossible (or the error will be high) according to following facts:

- there is no proof that the assumed time is an optimum one,

- there is no information what is the real level of work intensity assumed by a particular contractor.

The attempt to estimate the time for work execution based on the cost, results in an approximate answer too. As shown in fig. 3, for the cost $c$, it is possible to estimate the minimum and maximum time of the work execution.

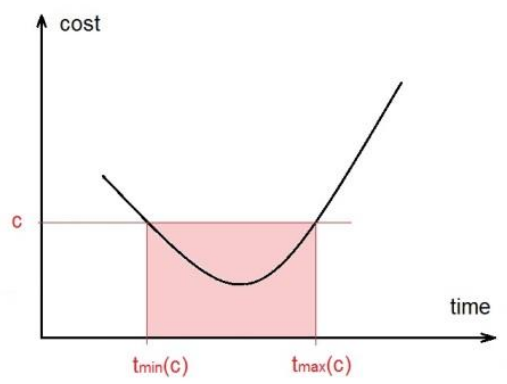

Fig. 3. The low precision of the evaluation of the time of work execution basing on its cost [own elaboration].

The conjunction $\mathrm{T}-\mathrm{C}$ between time and cost of building work execution is strong as remaining two (M-C, M-T), but according to its non-linear character, it is the most difficult to evaluate. In fact it is the only conjunction that can be currently applied by the clients (without applying CTM), as the information about means of production is strictly limited in tender documents.

\subsection{The requirements for CTM application}

In order to overcome the current situation, when the wide range of possible bid price can be accepted - even these under-priced - it is necessary to extend the scope of information provided by offerors in the tender documents. This will allow for CTM application for evaluation of the bid prices in a given tender procedure.

The tender documents should comprise:

- the price offer,

- the time schedule based on Critical Path Method [19], 
- the schedules of employment of the core building machinery,

- the schedule of the workers' employment

- the list of core building materials with their volume (or number, or weight).

The critical point is that all schedules mentioned above, should detect an identical level of details as the price offer, i.e. every element from the price offer (having there its number, description and the price) should be represented in time schedules.

\subsection{The detection of the inconsistent offers with CTM}

The abovementioned conjunctions (T-C, M-C, M-T) are not equally strong, meaning that the evaluation simplicity of one conjugated value by the other is not identical.

Table 1. The level of difficulty in estimating $\mathrm{C}, \mathrm{T}$ and $\mathrm{M}$ basing on their conjugated parameters [own elaboration].

\begin{tabular}{|l|c|c|c|}
\hline \multirow{2}{*}{$\begin{array}{l}\text { Conjugated parameter } \\
\text { as the estimation basis }\end{array}$} & \multicolumn{3}{|c|}{$\begin{array}{c}\text { Level of difficulty in estimating the value } \\
\text { of a conjugated paramer }\end{array}$} \\
\cline { 2 - 4 } & Cost & Time & $\begin{array}{c}\text { Means of } \\
\text { production }\end{array}$ \\
\hline Cost & $\mathrm{n} / \mathrm{a}$ & High & Moderate \\
\hline Time & High & $\mathrm{n} / \mathrm{a}$ & Low \\
\hline Means of production & Moderate & Low & $\mathrm{n} / \mathrm{a}$ \\
\hline
\end{tabular}

Table 1 summarizes previous findings and gives an advise which of the checks of the offers placed should be done as a first one - the easiest one - M-T. While analysing a single task e.g making a cut, given:

- the number of machines (from machinery time schedule) with their key parameters,

- preparation time of the cut (from the time schedule),

- typical efficiencies for the set of assumed machines from [20],

it is easy to estimate if the assumed set of machines to make a certain cut in the assumed time [14]. Assuming one shift per day, the following formula can be used:

$$
t_{i}=\frac{V_{i}}{e_{i}}
$$

where:

$t_{i} \quad$ calculated time of $i-t h$ element of building works in days,

$V_{i} \quad$ volume of $i-t h$ element of building works,

$e_{i} \quad$ efficiency of the set of machines assigned to $i-t h$ element of building works per shift

The six exemplary offers for preparing $30.000 \mathrm{~m}^{3}$ of a cut in 20 days are shown in tab. 2. The types and the number of diggers of each type can be read from machinery employment schedule, the time of cut preparing from the time schedule. The unit efficiency of each type of a digger is based on [20]. It can be noticed that the offer A should not be considered as it proposes an insufficiently low number of low-efficiency diggers [15]. It is practically impossible to make $30.000 \mathrm{~m}^{3}$ cut in 20 days with the machinery proposed in offer A. Keeping the scheduled 20 days based on the offer D is doubtful too. In order to compare the prices of the bid, the exemplary hiring prices of the machines (per day) were set here. Next, based on tab. 2. and tab. 3 the average cost for hiring the sets of machines separately for each bid - can be calculated and compared to the exemplary bid values - see tab. 4. The margin $g$ can be calculated too, for each offer as: 


$$
g=p-e
$$

where:

$p \quad$ the bid price,

$e \quad$ the estimated cost of the machinery

Table 2. Analysing the M-T conjunction for a cut making (planned $30.000 \mathrm{~m}^{3}$ in 20 days) for exemplary offers labelled from $\mathrm{A}$ to $\mathrm{F}$ [own elaboration] .

\begin{tabular}{|c|c|c|c|c|c|c|c|c|c|}
\hline 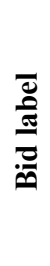 & 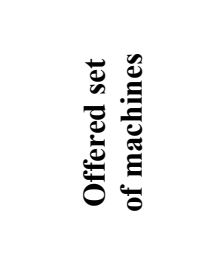 & 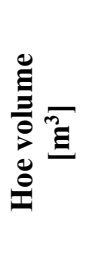 & 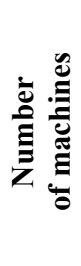 & 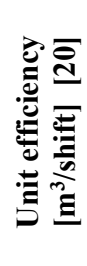 & 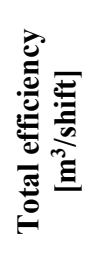 & 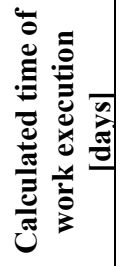 & 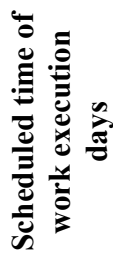 & 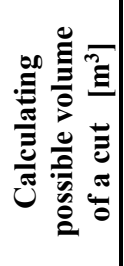 & 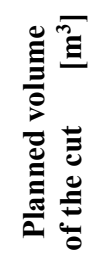 \\
\hline A & $\begin{array}{l}\text { Digger type X1 } \\
\text { Digger type X2 }\end{array}$ & $\begin{array}{l}0,6 \\
1,0\end{array}$ & $\begin{array}{l}2 \\
1\end{array}$ & $\begin{array}{l}330 \\
420\end{array}$ & 1080 & 27,8 & \multirow{6}{*}{20,0} & 21.600 & \multirow{6}{*}{30.000} \\
\hline B & $\begin{array}{l}\text { Digger type X1 } \\
\text { Digger type X2 } \\
\text { Digger type X5 }\end{array}$ & $\begin{array}{l}0,6 \\
1,0 \\
2,5\end{array}$ & $\begin{array}{l}1 \\
1 \\
1\end{array}$ & $\begin{array}{l}330 \\
420 \\
1260\end{array}$ & 2010 & 14,9 & & 40.200 & \\
\hline $\mathrm{C}$ & $\begin{array}{l}\text { Digger type X3 } \\
\text { Digger type } X 4\end{array}$ & $\begin{array}{l}1,2 \\
1,6\end{array}$ & $\begin{array}{l}2 \\
1\end{array}$ & $\begin{array}{l}470 \\
650 \\
\end{array}$ & 1590 & 18,9 & & 31.800 & \\
\hline $\mathrm{D}$ & Digger type X2 & 1,0 & 3 & 420 & 1290 & 23,8 & & 25.200 & \\
\hline E & $\begin{array}{l}\text { Digger type X1 } \\
\text { Digger type X3 } \\
\text { Digger type X4 }\end{array}$ & $\begin{array}{l}0,6 \\
1,2 \\
1,6\end{array}$ & $\begin{array}{l}2 \\
1 \\
2\end{array}$ & $\begin{array}{l}330 \\
470 \\
650\end{array}$ & 2430 & 12,3 & & 48.600 & \\
\hline $\mathrm{F}$ & $\begin{array}{l}\text { Digger type X4 } \\
\text { Digger type X5 }\end{array}$ & $\begin{array}{l}1,6 \\
2,5\end{array}$ & $\begin{array}{l}2 \\
1\end{array}$ & $\begin{array}{c}650 \\
1260\end{array}$ & 2560 & 11,7 & & 51.200 & \\
\hline
\end{tabular}

Table 3. The exemplary average prices of hiring the machine per day [own elaboration].

\begin{tabular}{|c|c|c|c|c|c|}
\hline Digger type & X1 & X2 & X3 & X4 & X5 \\
\hline Average hiring rate per day & 400 & 500 & 600 & 700 & 900 \\
\hline
\end{tabular}

Table 4. The estimated costs and bid prices comparison [own elaboration].

\begin{tabular}{|c|c|c|c|c|}
\hline Bid label & $\begin{array}{c}\text { Price per } \\
\text { day }\end{array}$ & $\begin{array}{c}\text { Cost estimation } \\
\text { for 20 days }\end{array}$ & $\begin{array}{c}\text { Bid } \\
\text { price }\end{array}$ & Margin \\
\hline A & 1300 & 26000 & 37000 & 11000 \\
\hline B & 2000 & 40000 & 45000 & 5000 \\
\hline C & 1900 & 38000 & 40000 & 2000 \\
\hline D & 1500 & 30000 & 39000 & 9000 \\
\hline E & 2800 & 56000 & 55000 & -1000 \\
\hline F & 2300 & 46000 & 48000 & 2000 \\
\hline
\end{tabular}

The margin is bound to be positive. It comprises all overheads and the necessary profit. The real cases of tender procedures, data collected from the actual bids can help the clients to evaluate which level of margin is usual, acceptable and typical for a given branch of the construction industry. Analysing only the bid prices from tab. 4 no one would say the price of the offer $A$ is under-estimated (see fig. 4). 


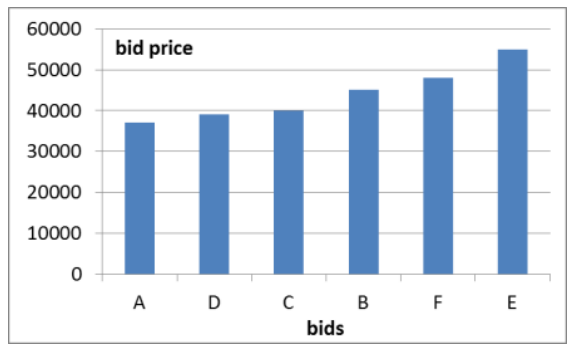

Fig. 4. The bid prices of the exemplary tender procedure [own elaboration].

The application of CTM allows for a double confirmation, that the lowest $A$ bid is inconsistent and has to be excluded (they are not technically prepared to make the 30.000 $\mathrm{m}^{3}$ cut in 20 days, and the margin is extremely high).

\section{Conclusions}

The Conjugated Triangle Method of the detection of inconsistent bids can be helpful especially in searching the under-priced offers - the source of many problems arising during construction work execution. It is based on the analysis of mutual conjunctions of three basic parameters: the cost, the time and means of production necessary to execute every building work. The relationships between the three parameters are common and natural. Application of the CTM does not require to disclose any information that currently is kept by the contractors as a secret one. Estimating the time of work execution (based on the proposed - in the offer - set of means of production), then estimating the contractor's price and comparing to the bid price can provide a precise answer if a given offer is underpriced. For the first part of analysis, the CTM can be applied for a single bid - no comparison to the other bids is necessary (it is not available without the CTM application). The two disadvantages of the CTM were found: the higher effort of the tender participants put in the bid preparing and the lack of possibility of CTM application in "design+build" projects. Nevertheless, where only the building works are ordered, a significant advantage of CTM, i.e. the precise information which offers are inconsistent, protect the clients from the choice of the offeror, whose falsely attractive bid price would be the reason for the client's loss.

\section{References}

1. B. Grzyl, M. Apollo, Umowa o roboty budowlane $w$ aspekcie podziału ryzyka stron. Inżynieria Morska i Geotechnika 6, 838-843 (2015)

2. B. Grzyl, E. Maliszewska-Urbańska, A. Siemaszko, Safety of investment process parties in the aspect of construction work contract. Journal of Science of the Gen. Tadeusz Kosciuszko Military Academy of Land Forces 49/4, 208-215 (2017)

3. B. Dao, S. Kermanshachi, J. Shane, S. Anderson, E. Hare, Exploring and assessing project complexity. Journal of Construction Engineering and Management, 10.1061/(ASCE)CO.1943-7862.0001275, 04016126 (2017)

4. H. Anysz, A. Foremny, J. Kulejewski, Estimating potential losses of the client in public procurement in case of collusion utilizing a MLP neural networks, Technical Transactions 111/1-B, 105-118, DOI: 10.13140/2.1.2409.6321 (2014)

5. S. Biruk, P. Jaśkowski, A. Czarnigowska, Modeling Contractor's Bidding Decisions, Procedia Engineering 182, 91-98, DOI: 10.1016/j.proeng.2017.03.125 (2017) 
6. S. Dubas, J. Pasławski, The concept of improving communication in BIM during transfer to operation phase on the Polish market, Procedia Engineering 208, 14-19, DOI: 10.1016/j.proeng.2017.11.015 (2017)

7. H. Anysz, Wykorzystanie sztucznych sieci neuronowych do oceny możliwości wystapienia opóźnień $w$ realizacji kontraktów budowlanych. Rozprawa doktorska, Wydział Inżynierii Lądowej PW, Oficyna Wydawnicza Politechniki Warszawskiej, DOI: 10.13140/RG.2.2.14129.68960 (2017)

8. H. Anysz, The profit as in-company evaluation of the construction site effectiveness. MATEC Web of Conferences 117, 1-6, DOI: 10.1051/matecconf/201711700009 (2017)

9. H. Anysz, Założenia systemu rozliczeń $T K W+M$ (techniczny koszt wytworzenia plus marża), Przegląd Budowlany 1 (2018)

10. A. Dziadosz, O. Kapliński, A. Tomczyk, M. Rejment, Analiza i ocena ryzyka finansowego w przedsięwzięciu budowlanym, Materiały Budowlanej 8, 112-113, DOI: 10.15199/33.2016.08.34 (2016)

11. J. Kulejewski, Zarzadzanie projektem wedtug PMBoK (cz. 1). Przegląd Budowlany 80/4, 47-53 (2009)

12. M. Banach, R. Marcinkowski, Harmonogramowanie robót budowlanych $z$ wykorzystaniem przedmiarów dodatkowych $w$ kosztorysowaniu, Materiały Budowlane 6, 6-7, DOI: 10.15199/33.2016.06.02 (2016)

13. M. Rogalska, Z. Hejducki, Time coupling methods construction scheduling and time/cost optimization, Wrocław: Oficyna Wydawnicza Politechniki Wrocławskiej (2011)

14. M. Krzemiński, The scheduling of construction work under the assumption of brigade multitasking, Procedia Engineering 208, 63-68, DOI: 10.1016/j.proeng.2017.11.021 (2017)

15. E. Plebankiewicz, J. Malara, The algorithm for the evaluation of construction workers' labour productivity, Technical Transactions, Y. 114/6, 153-161, DOI: 10.4467/2353737XCT.17.095.6571 (2017)

16. E. Radziszewska-Zielina, A. Sobotka, E. Plebankiewicz, K. Zima, Wstęnna identyfikacja i ocena parametrów wpływających na wydajność układu operatormaszyna do robót ziemnych, Budownictwo i Architektura 12(1), 53-60 (2013)

17. N. Ibadov, Selection of Construction Project Taking into Account Technological and Organizational Risk, Acta Physica Polonica A 132, 974-977, DOI: 10.12693/APhysPolA.132.974 (2017)

18. M. Juszczyk, A. Leśniak, K. Zima, Selected issues of bills of quantities in construction works in Poland, Journal of Science of the Gen. Tadeusz Kosciuszko Military Academy of Land Forces 49, 1(183), 189-200 (2017)

19. K. Jaworski, Metodologia Projektowania Realizacji Budowy, Wydawnictwo Naukowe PWN, Warsaw (2009)

20. Katalog Nakładów Rzeczowych 2-02, tab. 0218, Wacetob (1997) 